\title{
Narrative theology: An adequate paradigm for theological reflection?
}

\author{
Wentzel van Huyssteen \\ University of Port Elizabeth
}

\begin{abstract}
Narrative theology: An adequate paradigm for theological reflection?
\end{abstract}

As reflection on the religious claims embedded in stories, narrative theology touches the nerve of theology: what is the epistemological status of theological theories if they are based on discourse which is fundamentally narrative and metaphorical? This paper analyzes this question, along with the important differences between 'pure' and 'impure' narrative theology. Crucial problems arise from this and are discussed: the epistemological problem of determining criteria for assessing the truth claims of theological statements; and the hermeneutical criteria for distinguishing between good and bad receptions of Christianity's classic text.

In his recent seminal article entitled 'Two types of narrative theology', Gary L Comstock (1987a: 687) defines narrative theology as a reflection on the religious claims embedded in stories and regards this significant approach to theology as one of the most viable and important alternatives for doing theology today.

As a paradigm for postmodern theology, narrative theology grows directly from the deep conviction that temporal narrativity constitutes the substance of personal human identity: as such it is aimed at the ultimate interpretation of the 'story of our lives'. This basic narrative condition of what it means to be human, can also be described as the ontological condition for human stories of any kind: without it

This paper was presented at a Symposium on Narrative Theology at the Faculty of Theology (Section A) of the University of Pretoria, on March 7, 1989. 


\section{Narrative theology}

there could be no literature, no history, no philosophy and certainly no religion (cf Brockelman 1988: 2). Narrative theology takes this basic narrativity seriously in order to think through the nature of specifically religious knowledge.

Taking into account important German and British contributions, narrative theology still might be regarded as mainly an American contribution to postmodern anti-foundational theological thought. The historical starting point of narrative theology could most likely be linked to H Richard Niebuhr's (1941) essay entitled 'The story of our lives' (cf Comstock 1987b: 125). It is, however, especially since the 1970 's that this theme has become increasingly dominant. Today prominent although diverse theologians are associated with narrative theology: Paul Ricoeur, Hans Frei, David Tracy, George Lindbeck, Stanley Hauerwas, Sallie McFague, Johann Baptist Metz, Michael Goldberg, James H Cone, Ronald F Thiemann, Carol Christ, David Burrell, Harvey Cox and James McClendon, to mention but a few.

Despite the rapid growth of narrative theology it would appear that a definite tension has set in, dividing narrative theologians into two distinct groups, each with a more or less definable set of theological presuppositions and methodology.

For the sake of analysis these two groups of narrative theologians can be identified as pure narrativists and impure narrativists (cf Comstock 1987a: $688 \mathrm{ff}$ ). Pure narrativists can be described as anti-foundational, cultural-linguistic, Wittgensteinian-inspired descriptivists. For theologians like Frei, Lindbeck, Hauerwas and David Kelsey narrative as an autonomous literary form is particularly suited to theological reflection. Narrative here has a special status in the construction of theolngical statements, while abstract reasoning and philosophical categories do not belong to the essential task of what it means to do theology. Christian faith here is best understood by grasping the grammatical rules and concepts of its texts and practices.

Impure narrative theologians, on the other hand find their inspiration in the circle of revisionist, hermeneutical, Gadamerian-inspired correlationists (Comstock 1987a: 688). Theologians like Tracy, McFague and Ricoeur, while agreeing with 'pure narrativists' about the central role of narrative in the communication of the Christian story, deny it any exclusive autonomous theological function in theological theorizing. For them narrative exhibits philosophical, historical and psychological claims, and these need to be examined with the methods of those particular disciplines. In addition, pure narrative theologians very consciously construct a postmodern paradigm for theology, while impure narrativists creatively revise the paradigms of language, reason and practice of the liberal tradition in diverse attempts to justify the cognitive claims of theological reflection. 
The explicit tension in the ranks of narrative theology is already implicit in the work of H Richard Niebuhr, who - as 'father' of contemporary narrative theology made an important and far reaching distinction between 'internal' and 'external' history. Gary Comstock (1987b) supplies us with an illuminating analysis of this distinction: internal history has to do with the self-description of the Christian community in terms of their present experiences of the divine revelation; external history, on the other hand, is past history understood from the perspective of the observer - 'objective' history which could as such be subjected to the queries of scientific investigation.

For Niebuhr the very real tension between these two types of history had to be maintained: Christians must begin with their own present experiences of Christ, but should not isolate this from the criticism and correction of 'external' or scientific history. For Niebuhr Christians had to tell both stories, the internal history of our experiences with Christ as well as the external story of our experience with nature, history and science. Gary Comstock correctly states that present-day narrativists have been unable to tell 'the whole story' by opting for either internal or external history, giving rise to a new and improper tension between 'pure' and 'impure' narrativists (Comstock 1987b: $143 \mathrm{f}$ ). A way out of this impasse might be to find a way to reinterpret Christianity so as to be faithful to the biblical narratives, while at the same time remaining open to the philosophical and hermeneutical claims that result from the interpretation and explanation of these narratives.

Within the family of narrative theologians three common features or resemblances are shared, namely, description, explanation and justification. When, however, one examines the different ways in which narrativists decribe, explain and justify the Christian story, serious differences between the so-called pure and impure narrative theologians appear (cf Comstock 1987a: $690 \mathrm{ff}$ ). All narrativists agree that acceptable description should be conducted in terms of Scripture's own narratives and autobiographies and not in categories alien to the Biblical stories. An adequate explanation of the Christian story should be arrived at in terms of the internal rules and procedures of the Bible's own language game, and not in terms of imported philosophical theories or social-scientific laws. Justification of Christianity should take the form of pragmatic demonstration that this tradition entails a liberating and authentic form of life: a form of life and thought that does not need justification by means of philosophical criteria for rationality and logic (cf Pieterse 1989: 2 n.

It is, however, precisely on this point that serious differences between pure and impure narrativists appear: while, for example, purists do not reject critical thinking. they are wary of speculative reason and any attempt at a foundationalist epistemology. Because theology is fundamentally descriptive and regulative, it 
should not step outside the boundaries of the confessing community as the biblical narrative determines what can be said and done in theology. While purists have little or no room for the apologetic task of theology, 'impure' narrativists like David Tracy - while not discounting the centrality and power of the biblical narratives nevertheless deny absolute independence to narrative as such and argue that narratives contain all kinds of historical, psychological and metaphysical claims and therefore invite the critical inquiry of historians, feminists and philosophers.

A second deep rift between purists and impurists appear on the level of explanation. For a purist like George Lindbeck the Christian story posits a kind of language game sui generis, having its own unique procedures and rules. In this model doctrines are regulative rules for a confessing community and as such make no factual or ontological claims. While for this purist position it would be improper to explain the Christian story in terms of some other language game, for impure narrativists the Christian language game is in continual public conversation with other language games and should therefore be critically correlated with the insights of contemporary philosophers, ethicists and social scientists.

A third point of contention between purists and impurists centers around the justification of the Christian story. Pure narrative theologians want to bring theology to a complete halt once it has narratively described (and therefore explained) Christianity. Justification of the truth claims of the Christian faith is therefore of a pragmatic nature. On this impurists obviously disagree: according to them the truth claims of Christianity demand metaphysical inquiry in order to determine whether Christian beliefs are rationally acceptable, and whether there are ontological and/or epistemological grounds on which they can be justified (cf Comstock 1987a: $703 \mathrm{ff}$ ).

These important differences between pure and impure narrative theology at this stage already highlights two central problems for any contemporary theology:

- the epistemological problem of determining criteria for assessing the truth claims and cognitive status of theological statements;

- hermeneutical criteria for distinguishing between good or bad receptions of Christianity's classic text, and thus for assessing the validity of different interpretations of this text.

As reflection on the religious claims embedded in stories, narrative theology indeed touches the nerve of theology: what is the epistemological status of theological theories if they are based on discourse which is fundamentally narrative and metaphorical? With this in mind it is important to realize that in our age 
postmodern thought has highlighted the limits of human knowledge as well as a new understanding of the paradigmatic value of truth (cf Glanville 1989: 3). It is therefore perfectly understandable that a 'pure' narrativist like Ronald Thiemann can caution theology not to formulate a specific theory for understanding faith, because all such theories obscure both the diversity and the mystery of human response to the gospel: to acknowledge the biblical narrative as God's promise is to believe that the crucified Jesus lives (Thiemann 1987a: 38). In this sense a postmodern 'pure' narrative theology can even be seen as a call for a 'new Reformation': a new reformation to free Scripture once again, but this time from the papacy of the scholar (cf Wiles 1987: 44).

This specific kind of postmodern viewpoint, I have argued elsewhere (Van Huyssteen 1988: 12), eventually reduces theological reflection to a form of Wittgensteinian fideism while at the same time abandoning all truth claims as well as any plausible notion of explanatory progress for theological reflection. The hermeneutical and epistemological problems created by the divergent trends in contemporary narrative theology is especially highlighted by Thiemann's 'pure' form of narrative theology when the irrational inclusion of God as the hard core of a theological paradigm reveals a retreat to an esoteric commitment which firmly bars the way of theology to the reality about which it proposes to make statements. This is especially prominent in Thiemann's recent work (1987b) where he argues that the category of 'narrated promise' offers a non-foundational way of reconceptualizing Christian theology. This model for doing narrative theology becomes extra problematic when Thiemann contrasts narrative theology as descriptive theology with all forms of explanation, which for him always implies a foundationalist epistemology.

To counter this problem it is important to realize that biblical narratives are already interpretations, and biblical concepts in themselves are mini-theories that reveal the way in which the classic text of the Bible was received and interpreted through the ages.

The biblical narratives as we have them are therefore already interpretations, already seen through the eyes of faith. In this sense Janet Martin Soskice can correctly state: to narrate is to explain (Soskice 1988: 130). With this statement Soskice rightly exposes the fine division between narrative and discursive forms of theology as a naive and even potentially dangerous illusion (cf Jeanrond 1988: 158). Although narrative is an essential genre for communicating the Christian gospel, no form of 'pure narrative theology' will be able to solve the epistemological problems of contemporary theology. A non-foundationalist 'pure' narrative theology with its concern for a descriptive justification internal to the Christian framework, 
eventually reveals a peculiar brand of new-Wittgensteinian fideism. On this view religious beliefs have no need for explanatory support and in the end can hardly be seen as more than a groundless language game. In fact, these kind of beliefs become a species of belief whose truth is discovered by means of criteria internal to the language game itself (cf Steuer 1987: 241). The consequences of a so-called 'pure' narrative theology therefore becomes clear: Pure narrative theology not only leads to a relativistic understanding of justification, truth and knowledge, but also to an epistemological relativism which would be fatal for the cognitive claims of theological statements.

It is, however, of great importance to realize that the rationality of Christian theology is distinctively shaped by the fact that myths and metaphor are intrinsic to our knowing and naming of God, and that narrative is the very essence of the Christian faith. This essential narrativity of the Christian faith, as we have seen, does have a special appeal for postmodern theological reflection.

Any discussion of the merits of either 'pure' or 'impure' narrative theology will therefore have to include a careful analysis of what is meant by 'postmodern' as opposed to 'modern'. An analysis of the postmodern mentality as opposed to modernity is important not only because the rift within the family of narrative theologians can be largely reduced to this important conceptual problem, but also because it directly addresses the problem of fideism and foundationalism in contemporary theology. An analysis of these epistemological problems will eventually lead to an analysis of the hermeneutical problems implicit in all overt contextual theological models.

Futhermore: if postmodernism really is a departure from modernism and not merely a reaction to it, it could mean that the epistemological and hermeneutical problems connected with a modern paradigm are at best irrelevant to the postmodern approach (cf Pieterse 1989: 5). This could mean that the so-called 'resemblances' identified by Gary Comstock between pure and impure narrative theology - namely description, explanation and justification - could well designate a far greater incommensurability between the two approaches to doing theology than initially conceived.

Narrative theology - in all its 'pure' and 'impure' forms - can in the end only be fully understood within the broader framework of postmodern thought. Postmodernism itself is more of an attitude than a specific demonstrable trend or paradigm (cf Du Toit 1989). Typical of postmodernism is its scepticism concerning the central role assigned to reason and rational thought. Over against indubitable truth claims, an over confident faith in science and a metaphysical way of reasoning, the interrelatedness of truth-perspectives, ethical pluralism and cultural relativism is 
typical of the postmodern perspective.

Over against a literal and empirical understanding of knowledge and truth, postmodernism emphasizes the linguistic dimension of human nature, as well as the deep conviction that temporal narrativity constitutes the substance of what it means to be human. Within this postmodern framework literal language is replaced by an awareness of the metaphoricity and relationality of all language, but especially of religious language. Religious narrative thus seeks to make life's ultimate hermeneutical goal known: through narrative past events become 'graspable' and creates an awareness of a transcendental reality 'beyond' this world (cf Glanville 1989: 5). It is through myth and metaphor that this 'beyond' is actualized in our experience and understanding. Religious narrative leads us to see "through the window' of metaphor, to the way we ought to believe. Epistemic access through metaphor is therefore neither empirically deductive, nor literally true, nor subjective illusion.

For this reason Janet Martin Soskice, in answer to the question 'what would the epistemological status of theological concepts be if they were not based on a discourse which is fundamentally narrative and metaphorical?', can correctly claim: whatever they would be, they would not be Christian (cf Soskice 1988: 131).

For the same reason a pure narrative theology that consciously brackets the question of truth and validity, can only be seen as a kind of sectarian instrumentalism: a narrative theology which achieves a meaningful Christian story at the cost of detaching this story from any dialogue with other Christians and with the secular world.

When the problem of the justification of the cognitive claims of theological statements are considered, the central role of metaphor now becomes crucial. The reason why it becomes so important to single out the role of metaphorical language in religious texts is precisely because of the function of these metaphors. Metaphors certainly do not function only to 'name' something: on the contrary, they provide epistemic access to that which is being referred to. As such they function to catch great strands of association, conscious and perhaps unconscious, for readers of a certain religious tradition (cf Soskice 1988: 134). This does not mean that what metaphor gives epistemic access to and 'catches' as meaningful, is not real: what the metaphor catches or opens up is closely connected to the overall narrative construction of the texts involved.

In this sense theology basically reflects on religious experience and the ensuing religious language as ways to the reality we call God. But these experiences, and their accompanying metaphorical language, can only be reliably interpreted on the basis of the classic texts of the Christian faith. In this sense the text of the Bible, as 
the ultimate 'way' to the reality that is God, in itself becomes a reality that epistemologically functions as a very exclusive access to the reality of God. To this I have previously referred as the realism of the text (Van Huyssteen 1987: 30).

Within the context of this biblical text, narrative can be seen as a particular kind of textual structure characterized by its sequential, story-like qualities (cf Soskice 1988: 135). From this logically flows that not all biblical genres can be regarded as narrative, and certainly not all biblical metaphors are parts of narrative structures. This eventually will imply that theological reflection can never be exclusively defined in terms of only one biblical genre, however important it may be.

Narratives, as first order accounts, histories or stories, in a sense is even opposed to theology as a second order reflection on the classic texts and Christian experience. The popularity of a narrative theology - especially a 'pure' form of narrative theology - certainly is also concerned with reconfirming the place of the Bible in Christian life and thought. But, as Janet Martin Soskice has recently pointed out: one reason for the popularity of the narrative theology paradigm is that it effectively brackets the question of truth (Soskice 1988: 139). This obviously also is the reason why many postmodern theologians feel comfortable with the narrative theology paradigm: both accurate historical reports as well as pure fiction can be narratives, and epistemological truth claims - however provisional - are sacrificed to the supremacy of narrative meaning. And when in this way a narrative interpretation becomes a narrative theology, at least a few epistemological eyebrows should be raised (cf Soskice 1988: 139), because narrative in this mode is a retreat into the ghetto of a world created rather than illuminated by the scriptural text (cf Wiles 1987: 49).

Narrative, then, although an essential genre for communicating the Christian faith, by itself will not solve the epistemological problem of the shaping of rationality in contemporary theology.

A pure narrative theology that brackets the problem of the justification of the cognitive claims of theological statements, in the end ignores the question of truth and the problem of the shaping of rationality in theological reflection. It also bypasses the problem of reference or reality depiction, as 'pure' narrativists see the problem of justification in religious faith as entirely an internal, pragmatic matter. The cognitive claims of the Christian faith should be justified not only by their pragmatic effect and transformative power, but also by other epistemic values like reality depiction, contextuality, problemsolving and explanatory progress. A theology that takes these implicit philosophical and epistemological claims seriously, could well be called an 'impure narrative theology'. From a contemporary philosophy of science point of view, a weak form of critical realism can provide 
epistemic warrants for the rationality of such an 'impure' narrative theology: an antifideist and non-foundational theology that still has a valid place within the postmodern paradigm. Such a theology not only takes the problem of the shaping of theological rationality seriously: it also takes seriously the inescapable relation of theology to religious experience, to metaphor and to story.

Against this background it would be rather naive to think that narrative as a biblical genre is precritical, pre-interpretative and thus always preferable to interpretation, justification and argumentation (cf Jeanrond 1988: 151). All forms of theological communication contain interpretative elements, take sides, reveal particular perspectives and therefore needs critical assessment.

It now also seems that the question of an adequate theory of reference in theological theory formation must remain on the agenda of all forms of narrative theology.

Our discussion has shown that even in a postmodern paradigm it seems to be impossible to bracket the epistemological problems of validity, credibility and truthfulness when dealing with religious narratives. For this reason systematic theology will have to deal responsibly with a valid theory of metaphorical reference as a logical result of the basic realist assumptions and commitments of Christian theology.

With this in mind it becomes doubtful whether Gary Comstock's assertion that the Jewish theologian Max Kadushin's system of value-concepts does in fact provide an answer to the present dispute between pure and impure narrativists (Comstock 1989), can be regarded as epistemologically convincing. Kadushin analizes the interpretative role of value-concepts or control beliefs that provide us with a picture of the text-reader relationship. Value-concepts from the Torah, like charity, kingship, holiness and prayer cannot be pinned down by objective description but nevertheless have great pragmatic weight. These value-concepts guide behaviour and express the self-identity of successive generations of God's people. Comstock uses this approach as a resource for understanding Christian narrative and its appeal to the quality of one's entire life before God. It is, however, not clear how Comstock hopes to transcend the pragmatic criterion of pure narrative theology by appealing to value concepts when interpreting central Christian narratives. I am not convinced that he has succeeded in resolving the epistemological and hermeneutical problems referred to above.

In conclusion: the realist choice implied by a non-foundational impure narrative theology is justified only by uncovering the basis of Christian narrative in history.

It has already become clear that the only way we can manage to say anything about God at all is through our extended concepts, that is through analogies and 
metaphors. The important and final question that now arises, is: do we have good enough reasons to believe that these extended concepts are managing to do what we think they are doing, that is managing to refer, to 'get hold of reality?'

To ask this is to ask for adequate epistemological reasons for a weak form of critical realism in theology. I have suggested (Van Huyssteen 1987: 31) that the following could count toward a critical realist theory of metaphorical reference in Christian theology:

- The fact that the Bible, as the classic text of the Christian faith, has survived as a religious text and as a book of faith in a long and remarkable interpretative tradition of a still ongoing faith-context;

- The reality of ongoing faith experiences that this text has evoked through centuries of belief in God.

- The metaphorical nature of biblical language and the continuity of reference this has creatively given to religious and theological language through the ages. This presupposes a continuous language-using community going back to the 'initiating events' when these metaphorical terms were first introduced and their reference fixed.

I think one could safely say that the very reason narrative achieved such preeminence in Christianity is because of this religion's concern to show that God acts in the human world and its history: narrative becomes important for Christians and for Christian readings of the Old Testament because of the life of Jesus. In this sense one can rightfully claim: all forms of narrative theology grows from Christology (cf Soskice 1988: 150). Epistemologically then, this realist choice and the fixing of metaphorical reference is justified by uncovering the basis of Christian narrative in history.

And as to the events in the life and death of Jesus: one can only generalise from parable to myth and from myth to fiction if it can be shown that historical questions are irrelevant to a full and proper religious understanding of the gospel narratives.

\section{Works cited}

BROCKELMAN, P 1988. Narrative knowledge, religious truth and pluralism. Paper read at the Annual Meeting of the American Academy of Religion, Chicago, November 1988.

COMSTOCK, GL 1987a. Two types of narrative theology. JAAR 55/4. 
COMSTOCK, GL 1987b. Telling the whole story? American narrative theology after H Richard Niebuhr, in Frese, P (ed) Religion and philosophy in the United States of America. Essen: Vedrlag Die Blaue Eule.

COMSTOCK, GL [1989]. Max Kadushin among the narrative theologians. Modern Theology. (Forthcoming.)

DU TOIT, C 1989. Aspekte van die postmodernistiese idioom in die teologie. Theologia Evangelica.

GLANVILLE, $\mathrm{H}$ 1989. What is a Bongaloo, Daddy? On narrative knowledge, religious truth and pluralism. Paper read at the UPE Symposium on 'Narrative and interpretation', February 17, 1989.

JEANROND, W 1988. Response to Janet Martin Soskice. Proceedings: 7th European Conference on Philosophy of Religion. Utrecht University.

PIETERSE, H 1989. Gary Comstock's two types of narrative theology: An evaluation. Paper read at the UPE Symposium on 'Narrative and interpretation', February 17, 1989.

SOSKICE, JM 1988. Myths, metaphors and narrative theology. Proceedings: 7th European Conference on Philosophy of Religion. Utrecht University.

STEUER, AD 1987. The epistemic status of theistic belief. JAAR 55/2.

THIEMANN, RF 1987a. Radiance and obscurity in biblical narrative, in Green, G (ed), Scriptural authority and narrative interpretation. Philadelphia: Fortress.

THIEMANN, RF 1987b. Revelation and theology: The gospel as narrated promise. Notre Dame: University of Notre Dame Press.

VAN HUYSSTEEN, W 1987. The realism of the text. Pretoria: UNISA.

VAN HUYSSTEEN, W 1988. Inference to the best explanation? On narrative and the shaping of rationality in theological reflection. Paper read at the Annual Meeting of the American Academy of Religion, Chicago, November 1988.

WILES, M 1987. Scriptural authority and theological construction: The limitations of narrative, in Green, G (ed), Scriptural authority and narrative. Philadelphia: Fortress. 